\title{
The impact of ranitidine on monocyte responses in the context of solid tumors
}

\author{
Ava Vila-Leahey ${ }^{1,2}$, Dakota Rogers ${ }^{1,2}$ and Jean S. Marshall, ${ }^{1,2}$ \\ 1 Dalhousie Inflammation Group, Dalhousie University, Halifax, Nova Scotia, Canada \\ ${ }^{2}$ Department of Microbiology and Immunology, Dalhousie University, Halifax, Nova Scotia, Canada \\ Correspondence to: Jean S. Marshall, email: jean.marshall@dal.ca \\ Keywords: breast cancer, monocyte, MDSC, Immunology and Microbiology Section, Immune response, Immunity \\ Received: November 30, 2015 Accepted: January 16, $2016 \quad$ Published: February 05, 2016
}

\section{ABSTRACT}

Monocytes and myeloid derived suppressor cells (MDSC) have been implicated on the regulation of tumor growth. Histamine is also important for regulating MDSC responses. Oral administration of the $\mathrm{H} 2$ receptor antagonist ranitidine can inhibit breast tumor growth and metastasis. In the current study, we examined the impact of oral ranitidine treatment, at a clinically relevant dose, on multiple murine tumor models. The impact of ranitidine on monocyte responses and the role of CCR2 in ranitidine-induced tumor growth inhibition were also investigated. Oral ranitidine treatment did not reduce tumor growth in the B16-F10 melanoma, LLC1 lung cancer and EL4 thymoma models. However, it consistently reduced E0771 primary tumor growth and metastasis in the 4T1 model. Ranitidine had no impact on E0771 tumor growth in mice deficient in CCR2, where monocyte recruitment to tumors was limited. Analysis of splenic monocytes also revealed an elevated ratio of $\mathbf{H 2}$ versus $\mathrm{H} 1$ expression from tumor-bearing compared with naïve mice. More detailed examination of the role of ranitidine on monocyte development demonstrated a decrease in monocyte progenitor cells following ranitidine treatment. Taken together, these results reveal that $\mathrm{H} 2$ signaling may be a novel target to alter the monocyte population in breast tumor models, and that targeting $\mathrm{H} 2$ on monocytes via oral ranitidine treatment impacts effective tumor immunity. Ranitidine is widely used for control of gastrointestinal disorders. The potential role of ranitidine as an adjunct to immunotherapies for breast cancer and the potential impact of $\mathrm{H} 2$ antagonists on breast cancer outcomes should be considered.

\section{INTRODUCTION}

Monocyte recruitment is important for tumor progression [1-4]. A subset of monocytes will develop into tumor-associated macrophages; such cells can enhance tumor cell progression, angiogenesis, extravasation, metastasis, and resistance to chemotherapeutics [4-7]. Therefore a potential method to limit tumor progression would be to target monocyte development. Studies in mice have shown that there are alterations in tumor development when monocytes are depleted or their recruitment is inhibited [3,8-11]. In humans, treatments targeting monocytes are undergoing clinical trials $[11,12]$.

Monocyte development in the bone marrow of mice is dependent on monocyte colony stimulating factors, such as CSF1 $[13,14]$. Hematopoietic stem cells can develop into common myeloid progenitors (CMPs; Lin-Thy1-IL$7 \mathrm{R} \alpha{ }^{-} \mathrm{Sca}^{-}{ }^{-} \mathrm{c}-\mathrm{Kit}^{+} \mathrm{Fc} \gamma \mathrm{R} 1^{\text {lo }} \mathrm{CD} 34^{+}$) which have the potential to develop into granulocyte-macrophage progenitors (GMPs; Lin-Thy1'IL-7R $\alpha$-Sca1 ${ }^{-} \mathrm{c}-\mathrm{Kit}^{+} \mathrm{Fc} \gamma \mathrm{R} 1^{\text {hi }} \mathrm{CD} 34^{+}$) [15]. Subsequently such cells can go on to develop into macrophage and dendritic cell precursors (Linc$\left.\mathrm{Kit}^{+} \mathrm{CD} 115^{+} \mathrm{CD} 135^{+} \mathrm{Ly}^{-} \mathrm{CD}^{-} 11 \mathrm{~b}^{-}\right)$[16, 17], and then common monocyte progenitors ( $\mathrm{Lin}^{-} \mathrm{c}-\mathrm{Kit}^{+} \mathrm{CD} 115^{+} \mathrm{CD} 135$ Ly6 $\left.\mathrm{C}^{+} \mathrm{CD} 11 \mathrm{~b}^{-}\right)$[17]. These common monocyte progenitors may then develop into monocytes [17] which are $\mathrm{CD}_{11} \mathrm{~b}^{+}$Ly6C $^{\text {hi }}[16,18]$. The Ly6C ${ }^{\text {hi }}$ monocytes leave the bone marrow to be part of the peripheral blood monocyte population [16].

Once recruited into the circulation, the $\mathrm{Ly} 6 \mathrm{C}^{\mathrm{hi}}$ 
population can differentiate into Ly6C cow circulating monocyte population $[16,18]$, or be recruited to sites of inflammation where they can differentiate into monocytederived dendritic cells or macrophages [19]. These inflammatory monocytes are usually $\mathrm{CCR} 22^{\text {hi }} \mathrm{CX}_{3} \mathrm{CR} 1^{\text {low }}$. The Ly6Clow population is thought to "patrol" the endothelium and is involved in endothelial repair [20]. These cells are also required for the extravasation and tissue invasion of inflammatory monocytes during infection [21] and usually are $\mathrm{CX}_{3} \mathrm{CR}^{\mathrm{hi}}$. The inflammatory monocyte population is the predominant target for monocyte depletion with the aim of reducing tumor progression.

A subset of monocytes make up part of a group of cells noted as myeloid-derived suppressor cells (MDSCs). MDSCs are a population of immature monocytic and granulocytic cells that have immunosuppressive functions. With cancer progression, there are elevated levels of cytokines such as CSF1-3 and stem cell factor, which leads to abnormal myelopoiesis $[22,23]$ and an increase in immature myeloid cells in circulation [23], which can develop into MDSCs. Suppressive functions of MDSCs include inhibition of cytotoxic and helper T cell activation and proliferation [24], induction of $\mathrm{T}$ regulatory cells [25], reduction of NK cell activity [26], and induction of immunosuppressive macrophage phenotypes [27, 28]. MDSCs have been found to be a barrier to inducing an effective immune response against tumors, even in the context of immunotherapy.

Histamine is increased in concentration within tumors and regulates immunity [29, 30]. Histamine signals through four known histamine receptors (H1-4) which are differentially expressed on all immune cells, including monocytes and MDSCs. Monocytes can express $\mathrm{H} 1, \mathrm{H} 2$, and H4 [31-37], and MDSCs express H1-3 [3840]. $\mathrm{H} 2$ signaling has been implicated in the regulation of monocytes since it enhances CCL2 production and their expression of CCR2, which would enhance monocyte recruitment [41]. H2 signaling can inhibit production of cytokines such as TNF [42] and IL-27 [43] and also induces IL-1 $\beta$ production by monocytes [44]. H2 signaling also inhibits synthesis of reactive oxygen species in monocytes [45-47]. Yang et al [38] revealed that histamine signaling, primarily via $\mathrm{H} 2$ receptors, was important for MDSC function and that lack of HDC caused myeloid cells to remain in an immature state. Another study revealed that cimetidine, an $\mathrm{H} 2$ antagonist, inhibited nitric oxide synthesis and arginase I expression in monocytic MDSCs [39, 40], and caused MDSC apoptosis [40]. Histamine has also been shown to be important for inducing proliferation and survival of monocytic MDSCs through $\mathrm{H} 1$ and $\mathrm{H} 2$ signaling [39]. While functional aspects of MDSCs have been investigated, the impact of $\mathrm{H} 2$ signaling on monocyte and MDSC development is poorly understood.

$\mathrm{H} 2$ antagonist treatment can inhibit breast cancer development [48]. This is associated with a decrease in monocytes in the spleen and bone marrow. In the current study, we examined a variety of tumors and the impact of ranitidine on their development. Notably, ranitidine did not reduce tumor growth in several non-breast cancer models although it selectively reduced E0771 primary tumor growth and 4T1 metastasis. Using the orthotopic E0771 breast tumor model the impact of $\mathrm{H} 2$ antagonists was not observed in CCR2-deficient mice with defective monocyte recruitment. Further analysis revealed a difference in monocyte histamine receptor expression in tumor-bearing compared with naïve mice. Monocyte progenitors were decreased in non-tumor-bearing mice following ranitidine treatment. Populations of monocytes in tumor-bearing mice were also altered in the presence of ranitidine. These results reveal that enhanced tumor immunity in the presence of ranitidine is associated with changes in monocytic cell populations and is CCR2-dependent.

\section{RESULTS}

\section{Ranitidine does not alter tumor development in the absence of CCR2}

In previous studies we demonstrated that ranitidine treatment decreased 4T1 lung metastasis by $61 \%$ compared to control mice and reduced the growth of orthotopic primary E0771 breast tumors [48]. The impact of ranitidine treatment on tumor growth was further investigated using a panel of five tumor models; only E0771 primary tumor growth was significantly altered by ranitidine treatment (Table 1). Monocytic MDSCs have been implicated as important for the impact of ranitidine on breast tumor progression. We therefore analyzed the myeloid cell populations in tumor-bearing mice 7 days after tumor cell injection. The percentage of myeloid cell subsets in the spleen were unaltered in LLC1, B16-OVA, and EL4 following ranitidine treatment. The total number of monocytes in ranitidine-treated 4T1 tumor-bearing mice was previously found to be decreased by $46.3 \%$ ( $p$ $<0.005$ ) [48]. There were increased CD $11 b^{+}$myeloid cells in the spleen of ranitidine-treated E0771 tumor-bearing mice, and increased neutrophils in ranitidine-treated 4T1 tumor-bearing mice compared to control mice (Table 2). As ranitidine selectively decreased primary E0771 tumor growth and this was associated with myeloid cell changes we further analyzed the relationship between ranitidine treatment and monocytes in tumor development utilizing this model.

E0771 cells were injected into CCR2 ${ }^{-/-}$C57BL/6 mice. Analysis of blood from these mice showed decreased levels of monocytes in the CCR2 knockout mice compared to wild type mice $(2.0 \%$ vs $12.3 \%$ in CCR2- 
and wildtype mice, respectively). In control C57BL/6 mice, ranitidine caused inhibition of tumor development, starting at approximately day 13 of tumor development. In the $\mathrm{CCR} 2^{-/-}$mice, there was no difference in tumor growth or final tumor weight between ranitidine treated and control groups (Figure 1). These results demonstrate a critical role for CCR2 in the mechanism of action of ranitidine and suggest monocytes and/or recruitment of monocytes to the tumor may be important for the impact of ranitidine on tumor progression.

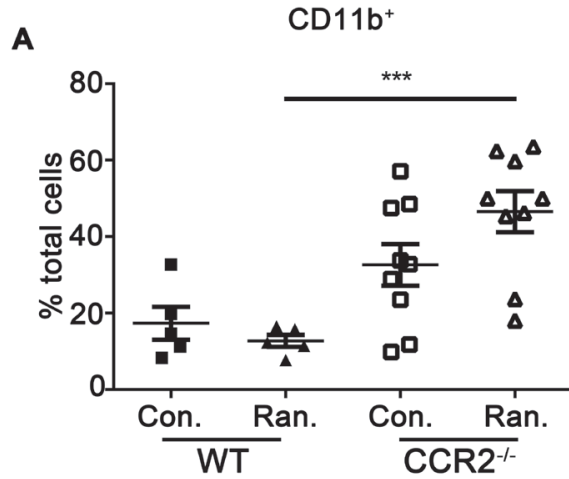

B

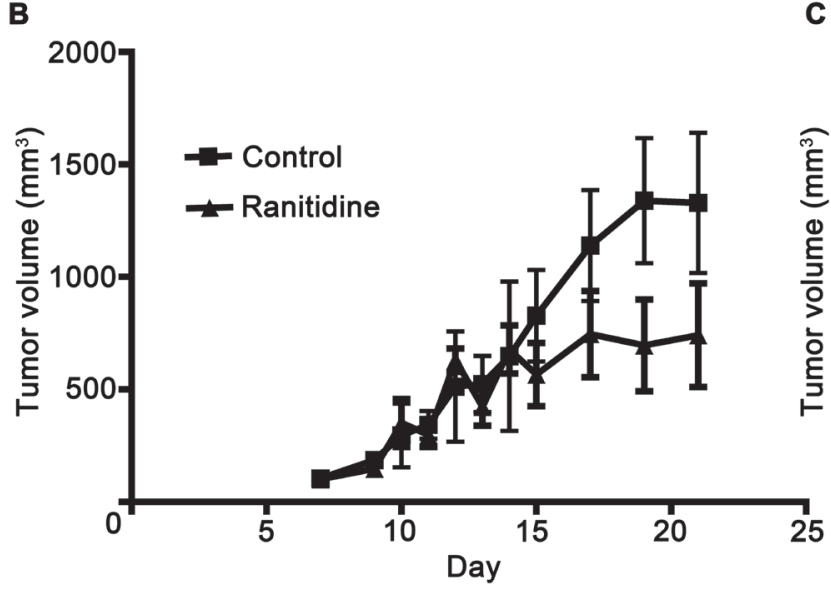

D

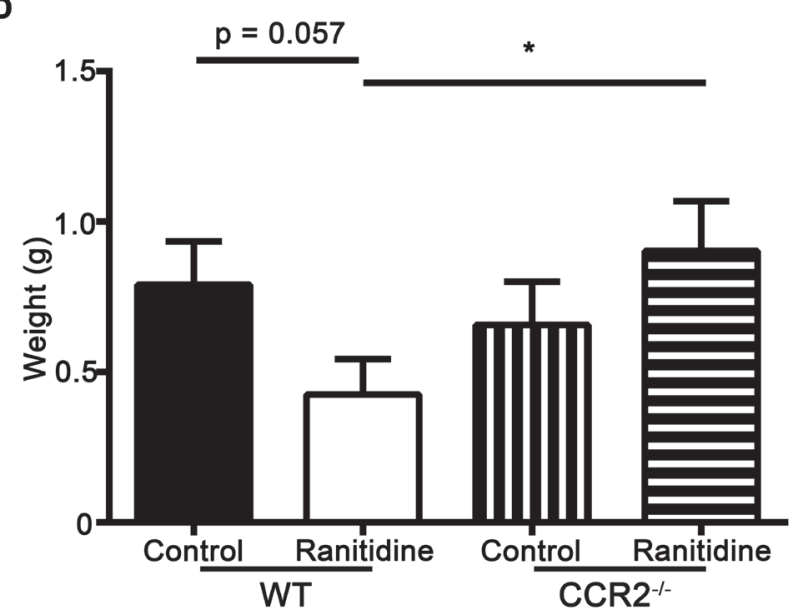

Ly6G+Ly6C 10

Ly6Chi
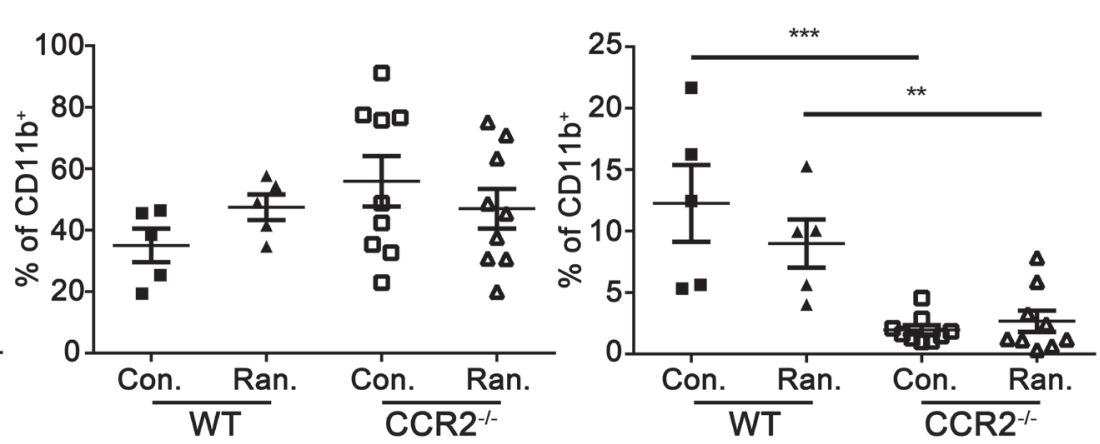

C

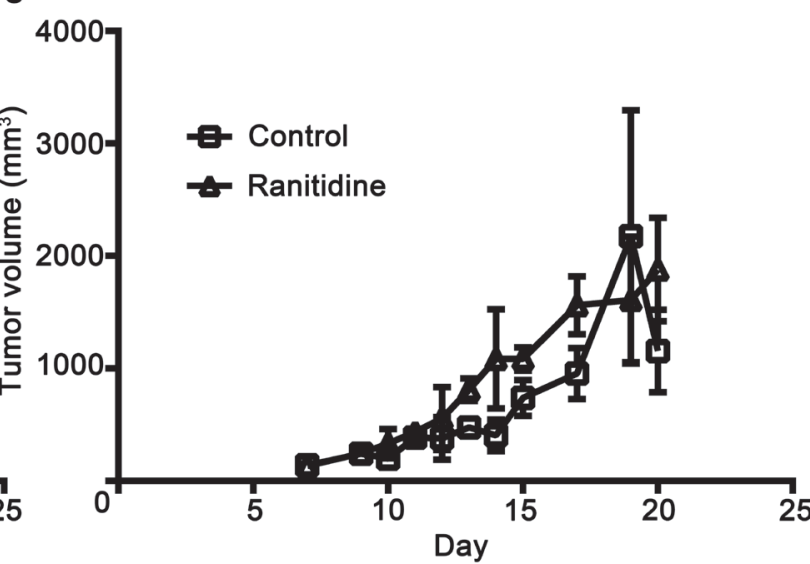

Figure 1: The impact of ranitidine on E0771 tumor progression is associated with changes in circulating monocytes. A. Composition of blood CD11 b cells, Ly6G+Ly6C $\mathrm{C}^{\text {low }}$ granulocytic cells, and Ly6C $\mathrm{C}^{\text {hi }}$ monocytic cells of E0771 tumor-bearing C57BL/6 (WT) and CCR2 ${ }^{-/}$C57BL/6 mice at day 21. E0771 tumors in C57BL/6 B. and CCR2 ${ }^{-/}$C57BL $/ 6$ C. mice treated with ranitidine $(8 \mathrm{mg} / \mathrm{kg}) \mathrm{were}$ measured every 2 days starting 7 days post E0771-GFP cell injection. D. At day 21, the primary tumor was excised and weighed. Data in A. represents individual mice and the line represents mean \pm SEM per group. Data points in B.-C. represents the mean \pm SEM tumor volume of 12-20 mice. Data points in D. represent final tumor weight of individual mice and line represents the average per group.* $p<0.05, * * p$ $<0.01, * * * p<0.001$, unpaired $t$-test. 


\section{Analysis of monocytes in E0771-bearing C57BL/6} mice

The nature of the monocyte populations in E0771 tumor-bearing mice with or without ranitidine treatment was further analyzed by flow cytometry. In naïve mice, the monocyte populations were not altered in either the spleen or the bone marrow following ranitidine treatment
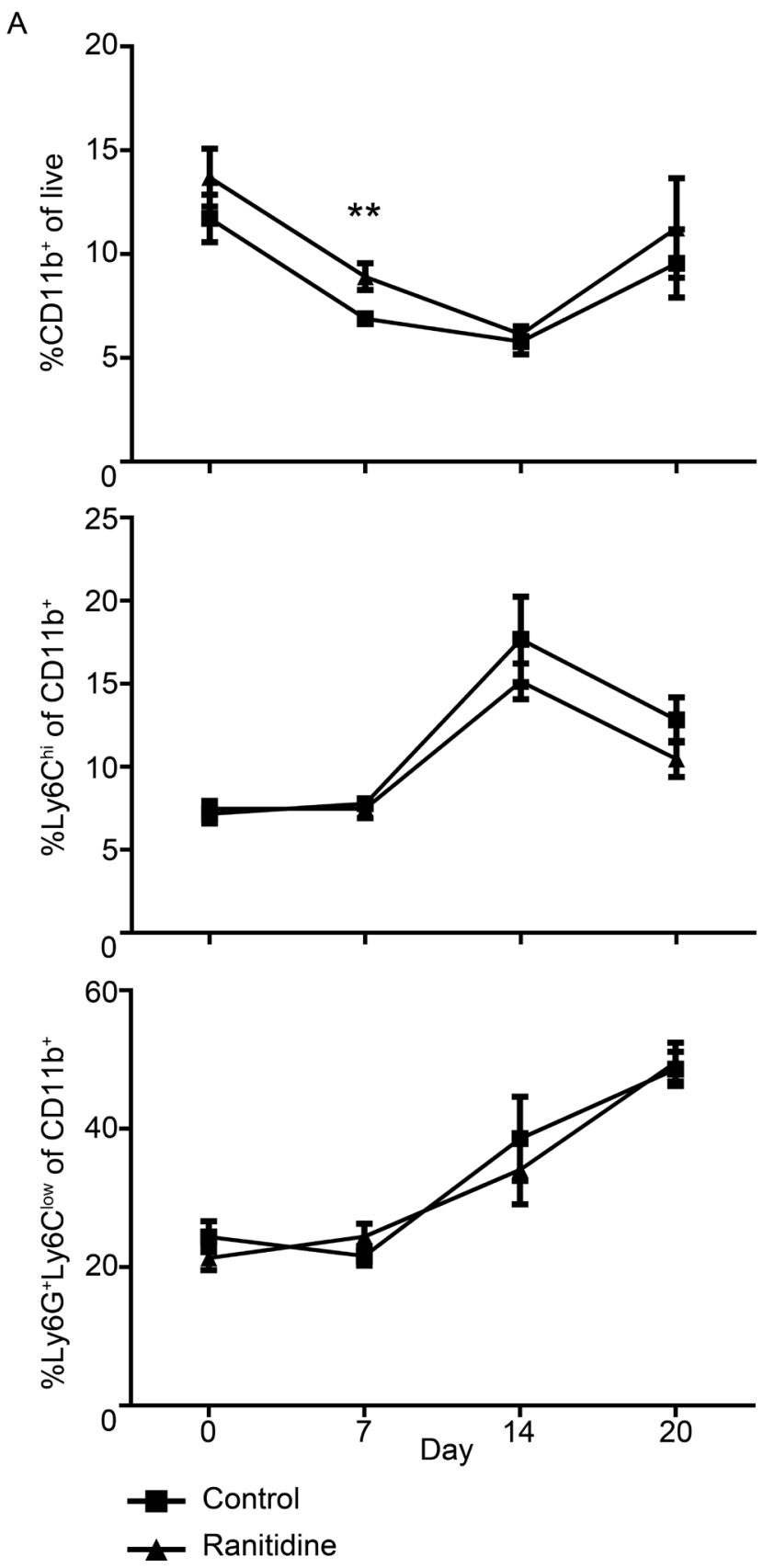

(Figure 2A). Seven days post tumor cell injection there was a small but significant increase in the overall numbers of myeloid cells in the spleen of ranitidine-treated tumorbearing mice compared with control tumor-bearing mice that was not due to alterations in identified monocytes or neutrophils (Figure 2B). Spleens and tumors were also analyzed 14 days post tumor cell injection. At day 14, a time point when tumor growth plateaus with ranitidine treatment, an increase in myeloid cells is seen at the

B
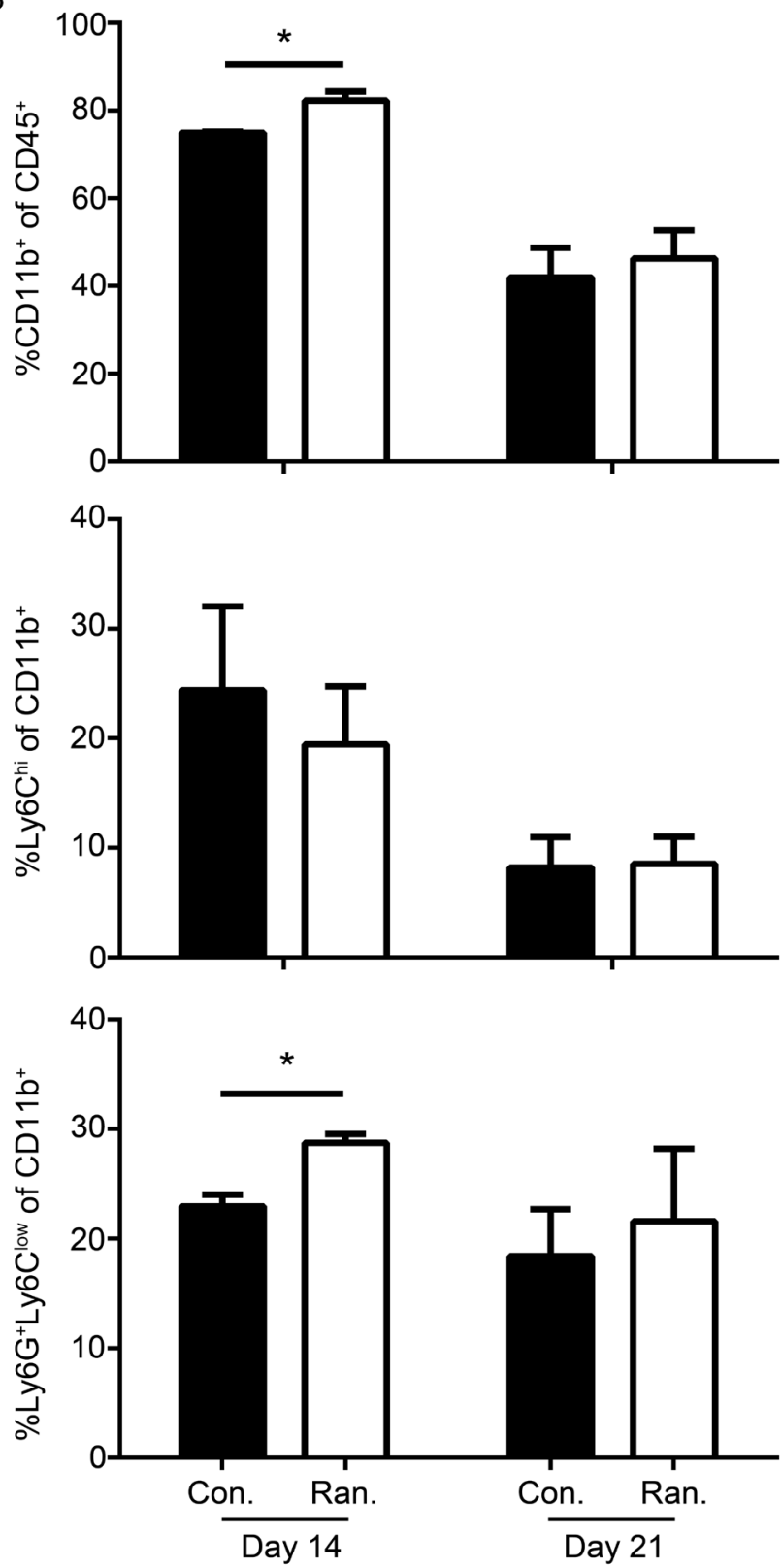

Figure 2: Alterations in myeloid cells at day 14 post E0771 cell injection. Composition of $\mathrm{CD}_{11 \mathrm{~b}^{+}}$cells, Ly6G $\mathrm{G}^{+} \mathrm{Ly} 6 \mathrm{C}^{\mathrm{low}}$ granulocytic cells, and Ly6C $\mathrm{C}^{\text {hi }}$ monocytic cells of splenic cells A., and isolated from the tumor B. from E0771 tumor-bearing mice over time. Day 0 in A. represent non-tumor-bearing C57BL/6 mice after 8 days of treatment, while the rest represent days after tumor cell injection. Data in A.-B. represents mean \pm SEM of 3-17 mice/group. ${ }^{*} p<0.05,{ }^{* *} p<0.01$, unpaired $t$-test. 
tumor site, associated with neutrophil recruitment (Figure 2B). There were no significant differences in the splenic myeloid cell populations at this time point, and no myeloid cell alterations in the spleen or in the tumor at the end point of the experiment (day 20) with ranitidine treatment.

\section{Ranitidine does not impact circulating monocytes}

Circulating monocytes were analyzed during tumor development to see if there were alterations in surface markers. We also analyzed whether there were any differences in CCR2 and CX3CR1 to determine if there were alterations in inflammatory monocyte numbers in

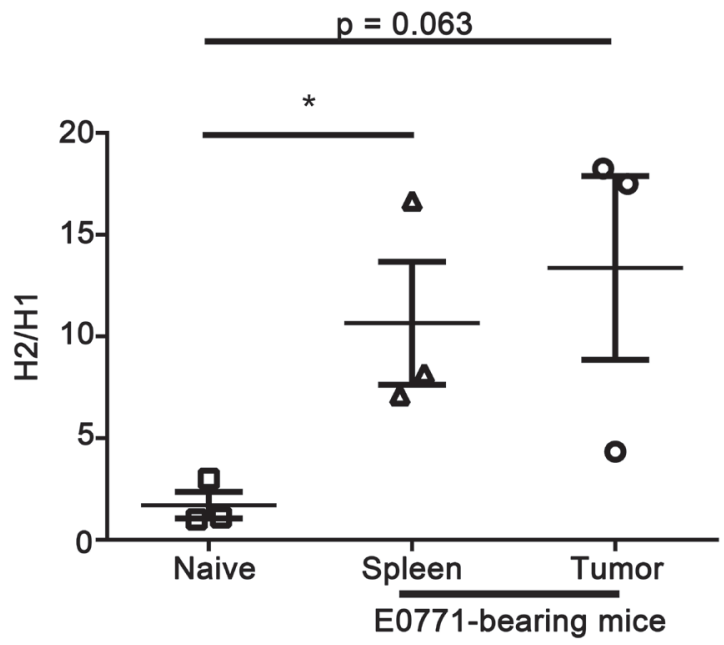

Figure 3: $\mathrm{H} 2$ levels are increased compared to $\mathrm{H} 1$ in monocytic MDSCs from E0771-bearing mice compared to naïve mice. qPCR on $\mathrm{CD}_{11} \mathrm{~b}^{+} \mathrm{Ly} 6 \mathrm{C}^{+} \mathrm{CD} 49 \mathrm{~d}^{+}$isolated from E0771 tumors, spleens from E0771-bearing mice, and spleens from naïve C57BL/6 mice was performed for detection of $\mathrm{H} 1$ and $\mathrm{H} 2$, and a ratio of $\mathrm{H} 2$ to $\mathrm{H} 1$ expression was calculated. Data points represent individual mice and line represents the mean \pm SEM per group. ${ }^{*} p<0.05$, unpaired $t$-test.
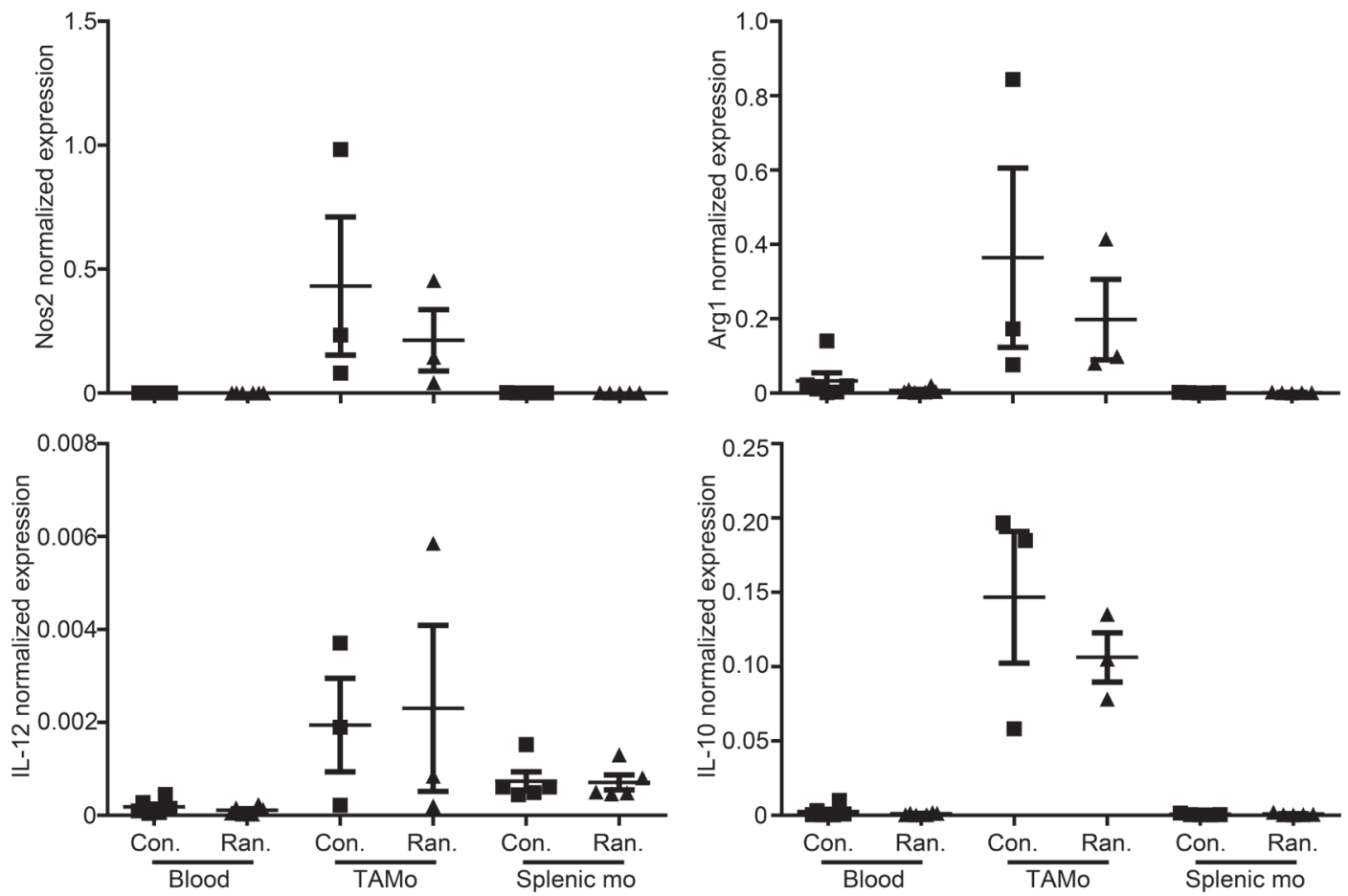

Figure 4: Ranitidine treatment does not alter mediator expression in monocytic MDSCs. qPCR on whole blood leukocytes and isolated $\mathrm{CD} 11 \mathrm{~b}^{+} \mathrm{Ly} 6 \mathrm{C}^{+} \mathrm{CD} 49 \mathrm{~d}^{+}$monocytic MDSCs from E0771 tumors (tumor-associated monocytes [TAMo]) and spleens (splenic mo) from E0771-bearing mice 14 days post tumor cell injection were performed for the detection of NOS2, Arg1, IL-12, and IL-10. Data points represent individual mice and line represents the mean \pm SEM per group. 
Table 1: Final tumor weights of histamine receptor antagonist-treated tumor-bearing mice

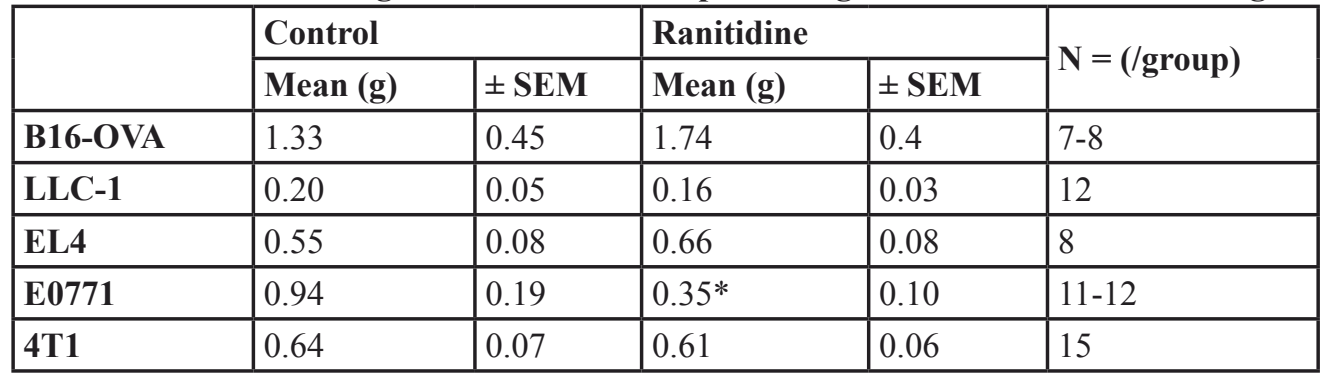

$* p<0.05$, unpaired $t$-test.

Table 2: Summary of the splenic myeloid population of histamine receptor antagonist-treated tumor-bearing mice 7 days after tumor cell injection

\begin{tabular}{|c|c|c|c|c|c|c|c|c|}
\hline & & \multicolumn{2}{|c|}{$\%$ CD11b+ of live } & \multicolumn{2}{|c|}{$\begin{array}{l}\text { \% Ly6C+ of } \\
\text { CD11b+ }\end{array}$} & \multicolumn{2}{|c|}{$\begin{array}{l}\text { \% Ly6G+Ly6Clow } \\
\text { of CD11b+ }\end{array}$} & \multirow[b]{2}{*}{$\begin{array}{l}\mathbf{N}=(/ \\
\text { group) }\end{array}$} \\
\hline & & Mean & SEM & Mean & SEM & Mean & SEM & \\
\hline \multirow{2}{*}{ B16-OVA } & Control & 10.78 & 0.82 & 7.42 & 0.38 & 19.5 & 1.36 & 14 \\
\hline & Ranitidine & 12.67 & 1.64 & 7.52 & 0.71 & 17.37 & 2.73 & 14 \\
\hline \multirow{2}{*}{ LLC-1 } & Control & 10.67 & 0.51 & 7.48 & 0.91 & 29.39 & 2.03 & 9 \\
\hline & Ranitidine & 13.45 & 2.67 & 7.16 & 0.67 & 28.38 & 3.09 & 9 \\
\hline \multirow{2}{*}{ EL4 } & Control & 15.35 & 1.88 & 6.54 & 0.88 & 19.2 & 2.40 & 9 \\
\hline & Ranitidine & 16.3 & 1.30 & 6.44 & 1.04 & 16.56 & 1.86 & 9 \\
\hline \multirow{2}{*}{ E0771 } & Control & 6.90 & 0.25 & 7.79 & 0.25 & 21.62 & 1.42 & 12 \\
\hline & Ranitidine & $8.92 * *$ & 0.65 & 7.50 & 0.60 & 24.44 & 1.83 & 12 \\
\hline \multirow{2}{*}{$4 \mathrm{~T} 1$} & Control & 8.26 & 0.64 & 7.96 & 1.00 & 32.70 & 1.94 & 13 \\
\hline & Ranitidine & 7.63 & 0.76 & 6.54 & 0.68 & $40.94 *$ & 2.83 & 13 \\
\hline
\end{tabular}

$* p<0.05, * * p<0.01$, unpaired $t$-test.

circulation in the context of ranitidine treatment. For these studies, mice were treated orally with ranitidine treatment initiated seven days prior to tumor cell injection.

Starting ranitidine treatment one week prior to tumor cell injection caused tumor growth to slow, to an equivalent extent as starting treatment one day prior to tumor cell injection (Supplementary Figure 1). Over the course of the experiment there was an increase in myeloid cells in circulation, but no significant alterations were seen in the total monocytic cells or in inflammatory monocytes in the circulation. However, at the end point of the experiment, there was a significant decrease in monocytes in the spleen in tumor-bearing mice treated with ranitidine compared with control tumor-bearing mice.

\section{Monocytes modify histamine receptor expression in the presence of a tumor}

Histamine receptors are known to be expressed on monocytes [31-37], and the ability of ranitidine and histamine to modulate MDSC function is highly dependent on histamine receptor expression. Therefore we examined the expression of histamine receptors on the subset of monocytes, with characteristics associated with MDSCs, during tumor progression.

Haile et al [49] describe that monocytic cells expressing CD49d are suppressive, therefore we sorted for CD11b ${ }^{+}$Ly6C ${ }^{\text {hi }}$ CD49d $\mathrm{d}^{+}$monocytic MDSCs and determined $\mathrm{H} 1$ or H2 mRNA expression by qPCR. Splenic monocytic MDSCs from tumor-bearing mice had a higher ratio of $\mathrm{H} 2$ to $\mathrm{H} 1$ compared to monocytic MDSCs from naïve mice (10.6 vs 1.7, respectively) (Figure 3 ). The ratio of $\mathrm{H} 2$ to $\mathrm{H} 1$ in tumor-associated monocytic MDSCs was also higher compared to naïve mice (13.4 vs 1.7, respectively).

\section{Ranitidine does not alter tumor-associated monocytes}

To analyze whether ranitidine alters monocytes in the spleen or tumor of E0771 tumor-bearing mice, monocytes were sorted by FACS in a similar manner as previously stated using the markers CD $11 \mathrm{~b}^{+} \mathrm{Ly} 6 \mathrm{C}^{\text {hi }} \mathrm{CD} 49 \mathrm{~d}^{+}$ for monocytic MDSCs, and expression of key mediators was assessed by qPCR. There were no significant 
A
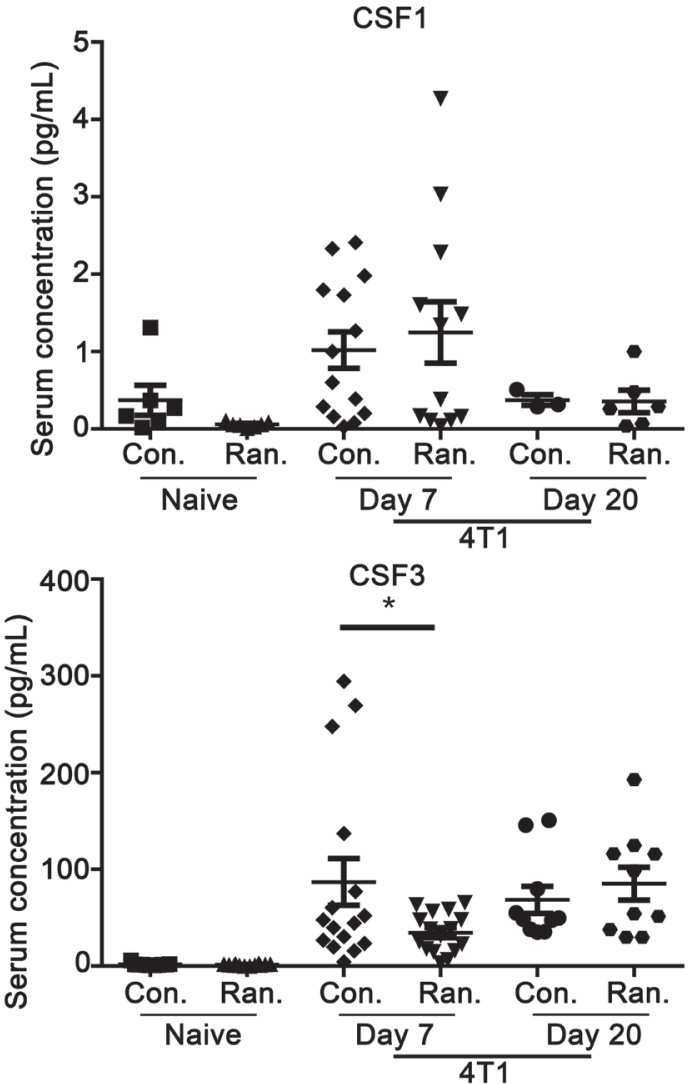

B
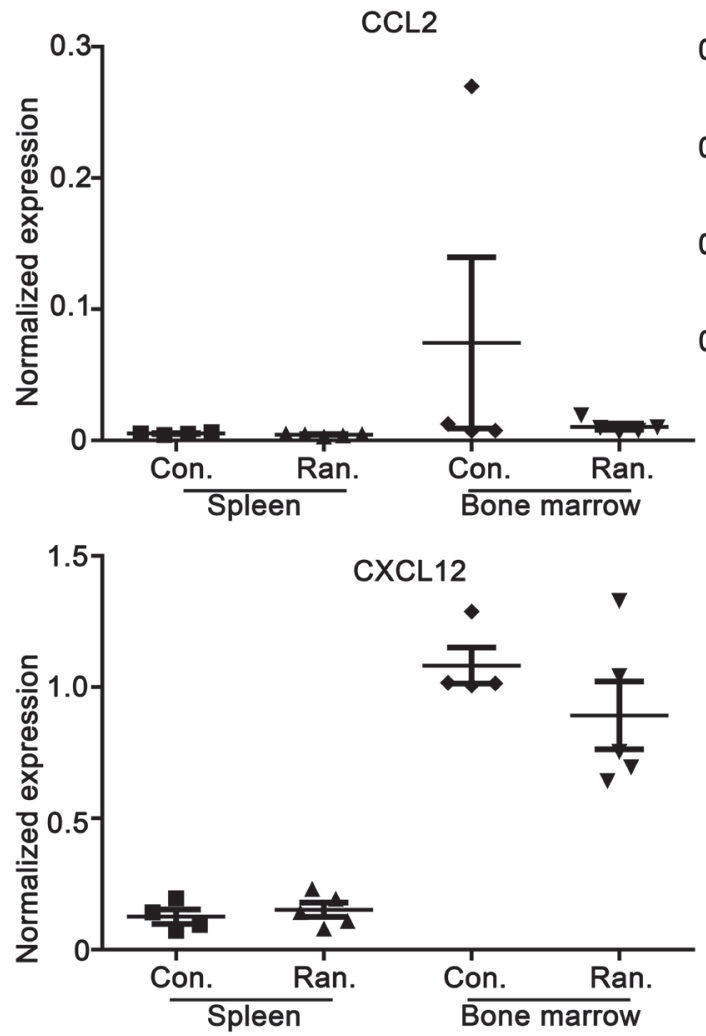

CSF2
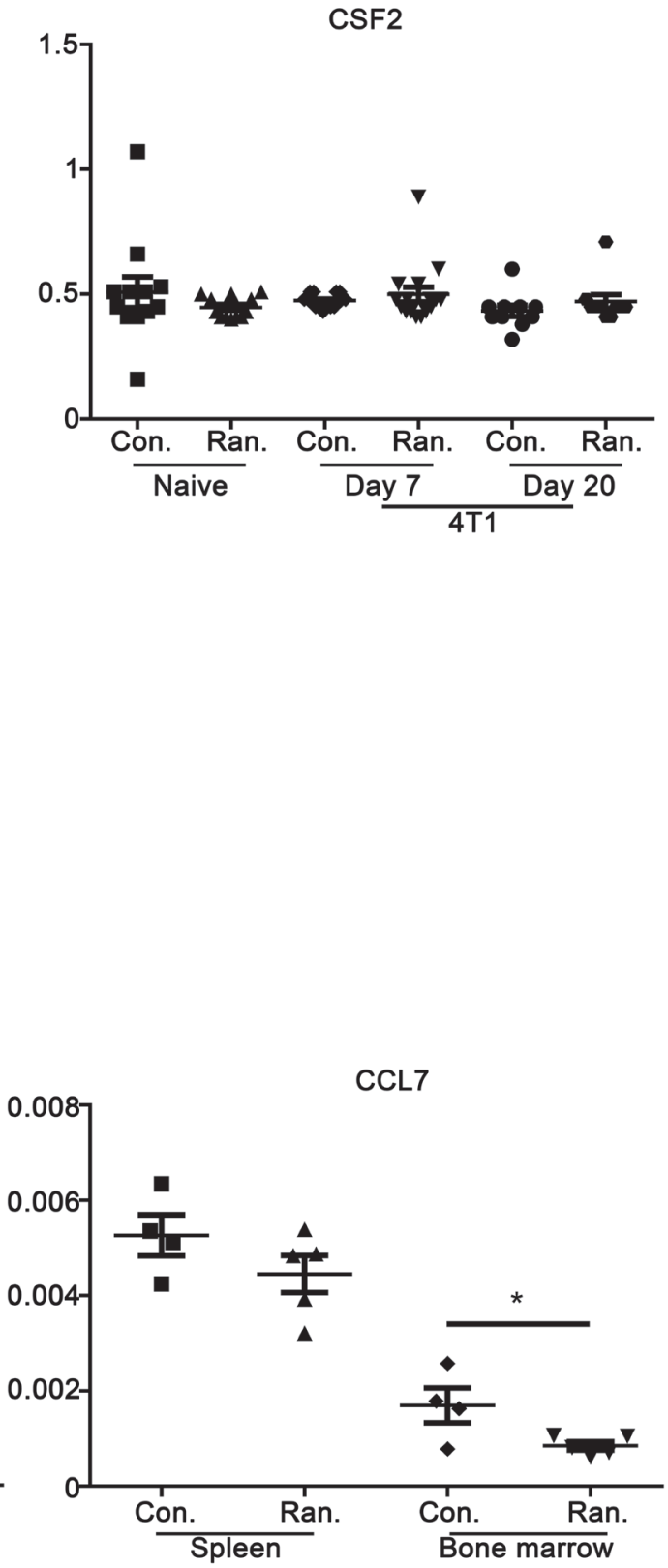

Figure 5: Ranitidine alters CSF3 in 4T1 tumor-bearing BALB/c mice after 7 days. A. CSF1, CSF2, and CSF3 levels in BALB/c naïve mice, and 4T1 tumor-bearing mice (7 days or 21 days after tumor cell injection) with and without ranitidine treatment was analyzed using Luminex. B. qPCR of splenocytes and bone marrow cells was performed for detection of CCL2, CCL7, and CXCL12. Data in A.-B. represent individual mice and line represents the mean \pm SEM per group. ${ }^{*} p<0.05$ unpaired $t$-test. 
alterations in any of the measured mediators between the control and ranitidine-treated groups (Figure 4).

\section{Analysis of mediators involved in monocyte differentiation and recruitment}

As monocytes are pivotal for tumor development and metastasis and ranitidine was shown to impact monocyte populations most strongly using the metastatic 4T1 tumor model, we utilized this model to further analyze the mechanism of monocyte modulation by ranitidine in tumor-bearing animals. Levels of mRNA expression and presence of mediators in the plasma that can alter monocyte differentiation and recruitment were determined. Analysis of plasma samples from BALB/c mice with and without ranitidine treatment for the presence of colony stimulating factors (CSF1-3) that are involved in myeloid differentiation showed no differences in naïve mice, but in 4T1 tumor-bearing mice there was a significant decrease in CSF3 at day 7 in the ranitidine-

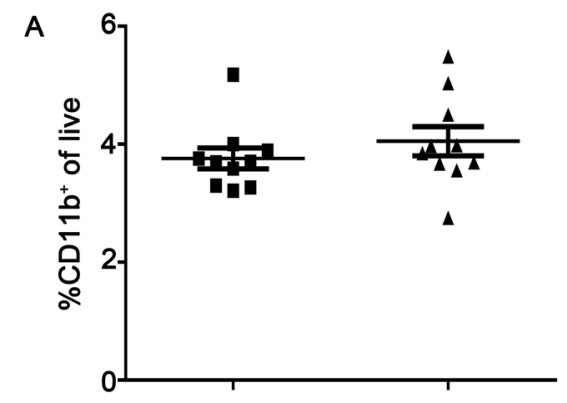

B
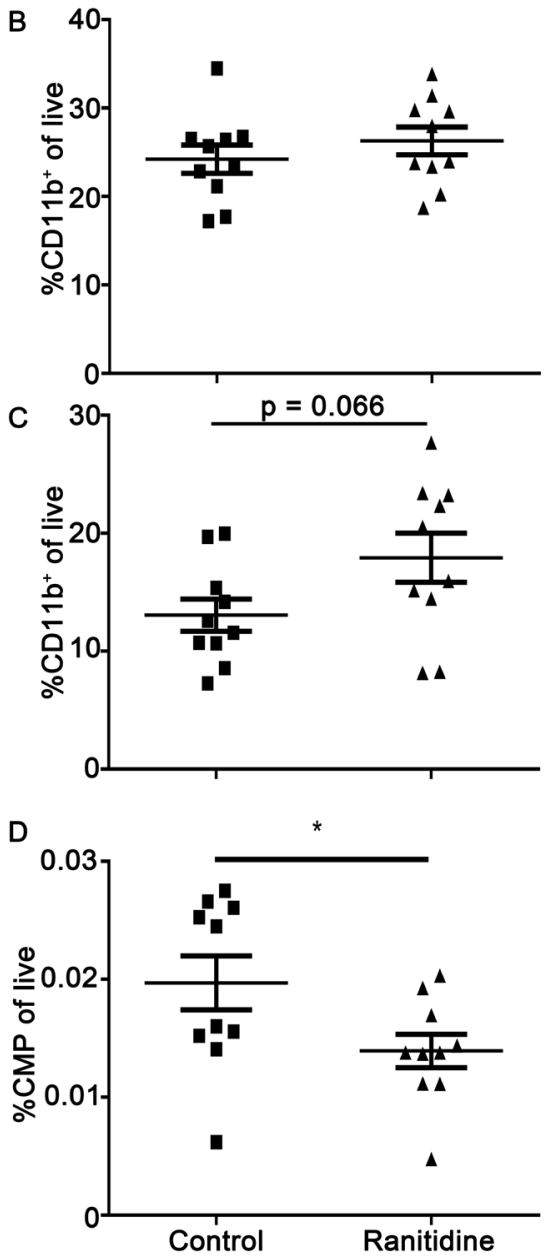
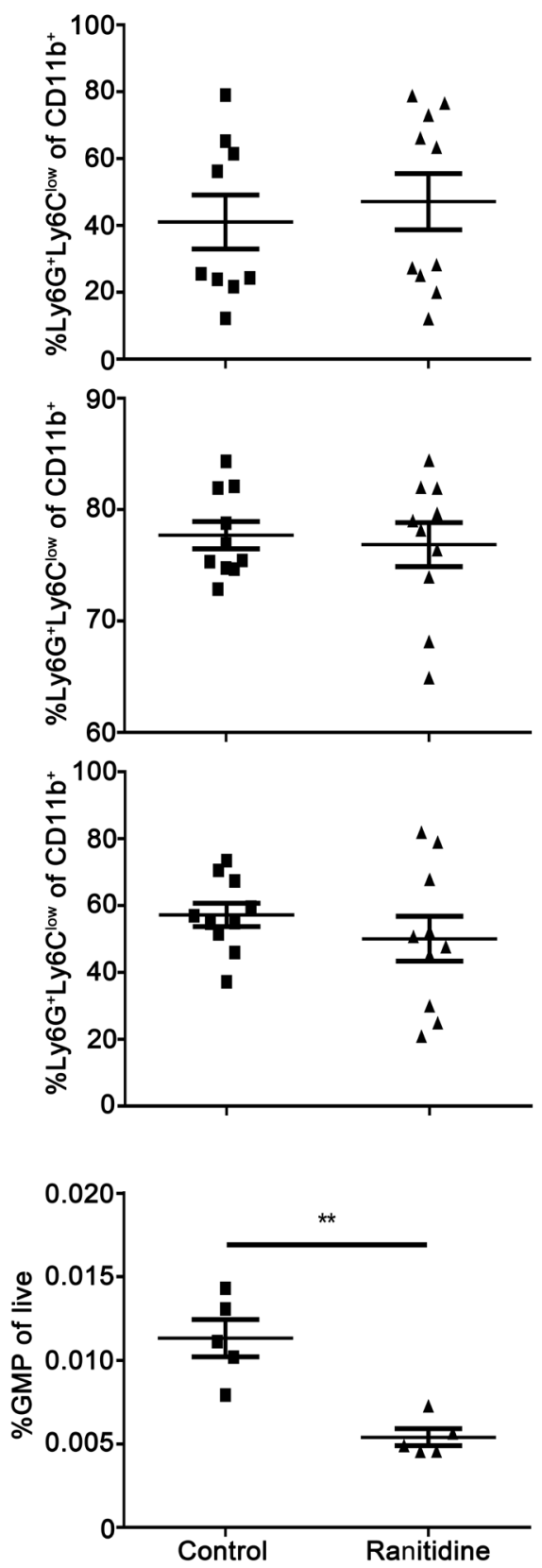
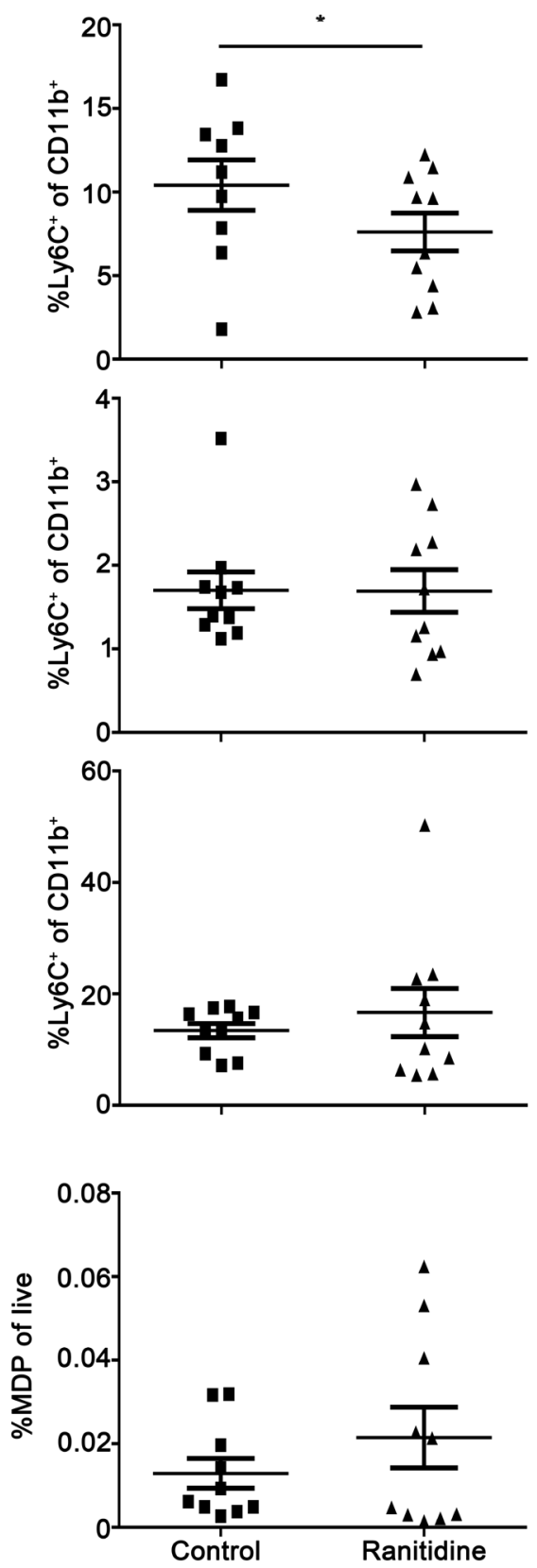

Figure 6: Ranitidine treatment causes a decrease in CMPs and GMPs in naïve BALB/c mice. A.-C. Composition of total

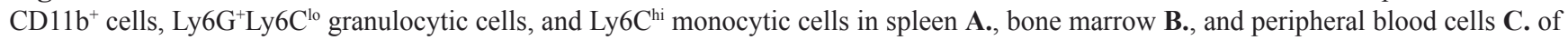
non-tumor-bearing mice with and without 6-9 weeks of ranitidine treatment. D. Composition of total CMP, GMP, and MDP cells in bone marrow. Data points represent individual mice and line represents the mean \pm SEM per group. $* p<0.05, * * p<0.01$, unpaired $t$-test. 
treated group, which disappeared after 21 days (Figure 5A). Levels of mRNA expression for chemokines that are important for recruitment of monocytes were also examined. Expression of CCL2, CCL7, and CXCL12 in the spleen and bone marrow in BALB/c mice, treated with ranitidine for 6-9 weeks, was determined. CCL2 mRNA levels were not altered in either area as a result of ranitidine treatment while CCL7 showed a trend towards a decrease in ranitidine-treated animals in the spleen, and significantly decreased in the bone marrow (Figure 5B). CXCL12 trended towards a decrease with ranitidine treatment but this was not statistically significant (Figure 5B).

\section{Long term ranitidine use alters splenic and bone marrow monocytes and progenitor cells}

The impact of ranitidine treatment on monocyte and monocyte-related progenitor cell populations in the bone marrow was also determined in a long term model using non-tumor-bearing animals. The spleen, blood, and bone marrow of $\mathrm{BALB} / \mathrm{c}$ mice that were treated with ranitidine for 6-9 weeks were examined in comparison with control mice. Long term ranitidine use lead to significantly decreased monocyte populations in the spleen (Figure 6A). Analysis of peripheral blood showed no significant alterations in myeloid cells, although there was a trend toward an increase in myeloid cells in the blood. The numbers of myeloid cells were not decreased in the bone marrow in these animals. When analyzing progenitor cells in the bone marrow, there was a significant decrease in GMPs and CMPs following ranitidine treatment (Figure 6D) but no significant alteration in monocyte progenitors downstream of GMPs. There were also no significant alterations in total splenocyte, bone marrow cell, and peripheral blood cell numbers.

\section{DISCUSSION}

Ranitidine is a widely used drug for the treatment of acid reflux, but also has an impact on immune cells. Although considered to be a safe drug with few side effects, the impact of consistent oral ranitidine on the immune system in a cancer setting has not been fully analyzed. Ranitidine is recommended for the treatment of the gastric side effects associated with chemotherapy [50]. Therefore understanding how clinically-relevant doses of ranitidine may impact the immune system in a tumor-bearing host is important. In our study long term ranitidine treatment was associated with a decrease in splenic monocytes and monocyte progenitors in the bone marrow. In breast tumor models, ranitidine limited tumor growth or metastasis, where altered monocyte populations were also observed. The impact ranitidine had in decreasing E0771 tumor growth was CCR2-dependent and therefore potentially linked to monocyte recruitment. Monocytic MDSCs from E0771 tumor-bearing mice had an increased ratio of $\mathrm{H} 2$ to $\mathrm{H} 1$ compared to naïve mice. The observed alterations in monocyte populations following ranitidine treatment have implications beyond breast cancer immunity.

After 8 days of ranitidine treatment, there were decreased monocytes in naïve and tumor-bearing $\mathrm{BALB} / \mathrm{c}$ mice; with long term ranitidine treatment there were significant differences in the monocyte population in the spleen, which were not seen in the bone marrow. Extramedullary hematopoiesis occurs in the spleen to create a monocyte reserve [51]; under steady state conditions monocytes can migrate back into the bone marrow and contribute to the monocyte pool [16]. There is therefore potential for ranitidine to have an impact on splenic progenitor cells in the spleen or in the bone marrow.

In humans, ranitidine treatment-associated myelodepletion is primarily considered to induce neutropenia [52] while, in mice, our studies suggest that ranitidineinduced myelo-depletion was monocyte specific. A previous study by Byron et al [53], showed that H2 signaling pushes bone marrow stem cells from $\mathrm{G}_{0}$ to $\mathrm{S}$ phase, therefore allowing for stem cell proliferation to occur. Our experiments support these data, but further show that this is specific to CMPs and GMPs. These results suggest that the mechanism of ranitidine-induced decreases in mature monocytes is via decreasing the number of monocyte progenitor cells. There is also potential that CMPs and GMPs are decreasing in numbers because they are being mobilized into circulation. Our data showed that ranitidine causes a decrease in CCL7 and a trend towards decreased CXCL12 (Figure 3), and CXCL12 is important for retention of stem cells in the bone marrow [54].

The impact of ranitidine on monocyte progenitors and mature monocytes has clinical implications, although there are very few studies that have directly examined these issues in humans. Decreases in monocyte numbers can further impact multiple different disease states. In a tumor setting, alterations in monocyte numbers and localization can lead to alterations in tumor infiltrate populations, including tumor-associated macrophages [7]. H2 antagonists are often prescribed to patients that are going through chemotherapy, therefore there is potential that $\mathrm{H} 2$ antagonist treatment might be beneficial. Alternatively, in patients with chronic inflammatory diseases where monocytes and MDSCs are important for regulating the immune response $[55,56]$, there is potential to exacerbate disease.

To our knowledge this is the first time differences in histamine receptor expression has been shown in monocytes in a tumor-bearing animal versus a naïve animal. High levels of histamine can increase H2 expression $[57,58]$ and there are elevated levels of 
histamine in breast cancer patients [29, 30]. H2 signaling is considered to create an immunosuppressive state, including enhancing MDSC survival [39, 40] and inducing mediators such as NOS2 and arginase [39]. $\mathrm{H} 2$ antagonists may also impact monocyte survival or the activation of MDSCs. Although MDSCs were isolated from both naïve and tumor-bearing mice, there were differences in receptor expression, suggesting that alterations in receptor expression, that may help promote the survival of MDSCs, may be another mechanism of inducing an immunosuppressive environment in the tumor microenvironment.

The use of CCR2 ${ }^{-/-}$mice compared with wild type mice revealed that the impact ranitidine has on tumor development in the E0771 model of breast cancer is CCR2-dependent. The CCL2-CCR2 axis is critical for recruitment of monocytes to the tumor [7]. Although CCR2 is found on other immune cells, the splenic monocyte and monocyte progenitor data provided supports that the CCR2-dependent effect we observed, is most likely due to monocytes. In humans, there is potential that $\mathrm{H} 2$ antagonists can directly impact the accumulation of neutrophils, or that neutrophil numbers are impacted indirectly by altered monocytes, as lack of monocyte recruitment can lead to enhanced neutrophil numbers in a tumor [8]. However, our data strongly implicates monocytes are the key cells in the ranitidine-dependent effect on breast tumor growth and spread.

In conclusion, we show that the impact of ranitidine on tumor development is associated with alterations in the monocyte population and associated progenitor cells. $\mathrm{H} 2$ blockade leads to a decrease in monocyte progenitors and alterations in myeloid cell numbers in the tumor. Inhibition of monocyte recruitment, through CCR2 deficiency, prevents the action of ranitidine in reducing tumor growth. These results suggest a mechanism by which $\mathrm{H} 2$ blockade can cause a decrease in tumor development when monocyte responses are important for tumor growth. The alteration in $\mathrm{H} 2$ expression in monocytic MDSCs suggests that specific blockade of $\mathrm{H} 2$ signaling in monocytes and MDSCs could inhibit their development. Overall, these data suggest that ranitidine usage may have effects on monocyte populations with far reaching implications for immune regulation in the context of both breast cancer and other diseases.

\section{MATERIALS AND METHODS}

\section{Cell lines}

Mouse melanoma B16-F10 transduced with ovalbumin (generously provided by Dr. John G. Frelinger and Dr. Edith Lord), mouse breast carcinoma 4T1, mouse lymphoma EL4, mouse lung carcinoma LLC1, and mouse breast adenocarcinoma E0771 (ATCC) transduced with GFP were maintained in a monolayer in Dulbecco's Modified Eagle's Medium (Hyclone) containing 10\% fetal bovine serum, and 1\% L-glutamine, HEPES, penicillin/ streptomycin; for E0771 $4 \mu \mathrm{g} / \mathrm{mL}$ of puromycin were added to media for selection of GFP-positive cells, and for B16-F10 $500 \mu \mathrm{g} / \mathrm{mL}$ of G418 was added to media for selection of ovalbumin-expressing cells.

\section{Mice}

All mouse experiments were pre-approved by the Dalhousie University Committee on Laboratory Animals. Five week old female BALB/c mice and C57BL/6 mice were purchased from Charles River Laboratories and housed in specific pathogen-free conditions at the Carleton Animal Care Facility at Dalhousie University. CCR2 knockout C57BL/6 mice were bred at the IWK Health Centre animal facility.

\section{In vivo orthotopic breast cancer model}

Ranitidine was added to drinking water one day prior to tumor cell injection and was refreshed every other day. 6-8 week old C57BL/6 and CCR2 ${ }^{-/-}$C57BL/6 mice (generously provided by Dr. Thomas Issekutz) were anesthetized and $2 \times 10^{5}$ E0771 cells in $100 \mu$ Matrige $^{\circledR}$ (Corning) were injected subcutaneously into the mammary fat pad near the fourth nipple. 6-8 week old BALB/c mice were anesthetized and $1 \times 10^{5} 4 \mathrm{~T} 1$ cells in $50 \mu \mathrm{L}$ PBS were injected subcutaneously into the mammary fat pad near the fourth nipple. The volume of the tumor was determined by caliper measurements every second day using the equation volume $=$ length $\mathrm{x}$ width $^{2} / 2$. At day 14 or day 21 post injection, the mice were sacrificed and the primary tumor, peripheral blood, and spleen were collected.

For analysis of circulating monocytes, starting one week prior to tumor cell injection and performed weekly, $100 \mu \mathrm{L}$ peripheral blood was isolated via facial vein bleed and processed for flow cytometry.

\section{Alternate tumor models}

A similar experimental layout was used as stated above. 6-8 week old C57BL/6 mice were anesthetized and $2 \times 10^{5}$ LLC1 cells in $50 \mu \mathrm{L}$ PBS, $1 \times 10^{5}$ B16-OVA cells in $50 \mu \mathrm{L}$ PBS, or $2 \times 10^{5}$ EL4 cells in $100 \mu \mathrm{L}$ PBS were injected subcutaneously in the back. At day 7 or day 14-15 (for LLC1 and EL4) or day 20-21 (for B16-OVA), the mice were sacrificed and the primary tumor, peripheral blood, and spleen were collected. 


\section{Flow cytometry}

Antibodies: Rat anti-mouse CD11b-fluorescein isothiocyanate (cat. \#11-0112, eBioscience), rat antimouse Ly6G-biotin (cat. \#12760, Biolegend), rat antimouse Ly6C-allophycocyanin (APC) (cat. \#17-5932, eBioscience), rat anti-mouse CD49d-phycoerythrin (PE) (cat. \#12-0492), rat anti-mouse CD62L-PE (cat. \#12-0621, eBioscience), rat anti-mouse Ly6C-PE-Cy7 (cat. \#255932, eBioscience), rat anti-mouse $\mathrm{CX}_{3} \mathrm{CR} 1-\mathrm{PerCP} / \mathrm{Cy} 5.5$ (cat. \#149009, BioLegend), rat anti-mouse CCR2-APC (cat. \#FAB5538A, R\&D Systems). Appropriate isotype matched control antibodies were used in all experiments.

E0771 tumors were digested in the following enzyme cocktail in HBSS: $4.48 \mathrm{U} / \mathrm{mL}$ Dispase (cat. \#17105, Gibco), $200 \mu \mathrm{g} / \mathrm{mL}$ DNAse I, $10 \mathrm{mM}$ magnesium chloride. The tumors were then pushed through a $100 \mu \mathrm{M}$ cell strainer and blood was lysed with ACK buffer $(0.15 \mathrm{M}$ ammonium chloride [cat. \#A4514, Sigma Aldrich], $0.01 \mathrm{M}$ potassium bicarbonate [cat. \#P7682, Sigma Aldrich], 0.07 mM EDTA [cat. \#15575, Invitrogen]).

Splenocytes, blood, and bone marrow cells were blocked in FACS buffer containing rat serum. Samples were then mixed with primary antibodies for 15 minutes on ice, washed, and mixed with streptavidin PerCP for 20 minutes at $4^{\circ} \mathrm{C}$. Following washing, cells were fixed with $1 \%$ paraformaldehyde (for acquisition) or resuspended in FACS buffer (for sorting) and acquired/sorted for analysis using a Becton Dickinson FACSAria II. Results were analyzed using FCS express software (De Novo Software).

\section{qPCR}

RNA from cells was isolated using the Qiagen RNA RNeasy Plus Mini kit and QIAamp RNA Blood Mini Kit. Reverse transcription was carried out using the Qiagen Quantitiect Reverse Transcription kit. For qPCR, cDNA was mixed with primers for GAPDH, HPRT, CCL2, CCL7, CXCL12, H1, H2, NOS2, Arg1, IL-10, IL-12 (Quantitect Primer Assay, Qiagen), and Promega GoTaq ${ }^{\circledR}$ qPCR Master Mix. The mixtures were then read in a Stratagene Mx 3000P using the MxPro program, using the following settings: $95^{\circ}$ for 5 minutes; 40 cycles of $\left(95^{\circ} \mathrm{C}\right.$ for 10 seconds, $60^{\circ} \mathrm{C}$ for 30 seconds); $95^{\circ}$ for 1 minute; $55^{\circ} \mathrm{C}$ for 30 seconds; $95^{\circ}$ for 30 seconds. The critical threshold $(\mathrm{Ct})$ of each sample was then obtained and used for normalization compared to the average $\mathrm{Ct}$ between GAPDH and HPRT.

\section{Luminex}

$25 \mu \mathrm{L}$ of serum from mice isolated via cardiac puncture was used for a ProcartaPlex ${ }^{\mathrm{TM}}$ Mouse Basic Kit (eBioscience) to detect CSF1, CSF2, CSF3, IL-6, IL-10,
IL-12, and TNF according to manufacturer's instructions

\section{ACKNOWLEDGMENTS}

Ava Vila-Leahey was supported by a trainee award from the Beatrice Hunter Cancer Research Institute (BHCRI) with funds provided by the Canadian Imperial Bank of Commerce as part of The Terry Fox Strategic Health Research Training Program in Cancer Research at the Canadian Institutes for Health Research (CIHR). Dakota Rogers was supported by a summer studentship from the Beatrice Hunter Cancer Research Institute in partnership with Mud Hero and an NSERC USRA.. This work was funded by the Canadian Cancer Society Research Institute, the CIHR (\#MOP93517).

\section{CONFLICTS OF INTEREST}

The authors have no conflicts of interest to disclose related to this study.

\section{REFERENCES}

1. Sanford DE, Belt BA, Panni RZ, Mayer A, Deshpande AD, Carpenter D, Mitchem JB, Plambeck-Suess SM, Worley LA, Goetz BD, Wang-Gillam A, Eberlein TJ, Denardo DG, Goedegebuure SP and Linehan DC. Inflammatory monocyte mobilization decreases patient survival in pancreatic cancer: a role for targeting the CCL2/CCR2 axis. Clinical cancer research. 2013; 19:3404-3415.

2. Roca H, Varsos ZS, Sud S, Craig MJ, Ying C and Pienta KJ. CCL2 and interleukin-6 promote survival of human $\mathrm{CD} 11 \mathrm{~b}+$ peripheral blood mononuclear cells and induce M2-type macrophage polarization. The Journal of biological chemistry. 2009; 284:34342-34354.

3. Qian BZ, Li J, Zhang H, Kitamura T, Zhang J, Campion LR, Kaiser EA, Snyder LA and Pollard JW. CCL2 recruits inflammatory monocytes to facilitate breast-tumour metastasis. Nature. 2011; 475:222-225.

4. Lu X and Kang Y. Chemokine (C-C motif) ligand 2 engages CCR2+ stromal cells of monocytic origin to promote breast cancer metastasis to lung and bone. The Journal of biological chemistry. 2009; 284:29087-29096.

5. Paulus P, Stanley ER, Schafer R, Abraham D and Aharinejad S. Colony-stimulating factor-1 antibody reverses chemoresistance in human MCF-7 breast cancer xenografts. Cancer research. 2006; 66:4349-4356.

6. Lin EY, Nguyen AV, Russell RG and Pollard JW. Colonystimulating factor 1 promotes progression of mammary tumors to malignancy. The Journal of experimental medicine. 2001; 193:727-740.

7. Cortez-Retamozo V, Etzrodt M, Newton A, Rauch PJ, Chudnovskiy A, Berger C, Ryan RJ, Iwamoto Y, Marinelli B, Gorbatov R, Forghani R, Novobrantseva TI, Koteliansky V, Figueiredo JL, Chen JW, Anderson DG, et al. Origins 
of tumor-associated macrophages and neutrophils. Proceedings of the National Academy of Sciences of the United States of America. 2012; 109:2491-2496.

8. Mitchem JB, Brennan DJ, Knolhoff BL, Belt BA, Zhu Y, Sanford DE, Belaygorod L, Carpenter D, Collins L, Piwnica-Worms D, Hewitt S, Udupi GM, Gallagher WM, Wegner C, West BL, Wang-Gillam A, et al. Targeting tumor-infiltrating macrophages decreases tumor-initiating cells, relieves immunosuppression, and improves chemotherapeutic responses. Cancer research. 2013; 73:1128-1141.

9. DeNardo DG, Brennan DJ, Rexhepaj E, Ruffell B, Shiao SL, Madden SF, Gallagher WM, Wadhwani N, Keil SD, Junaid SA, Rugo HS, Hwang ES, Jirstrom K, West BL and Coussens LM. Leukocyte complexity predicts breast cancer survival and functionally regulates response to chemotherapy. Cancer discovery. 2011; 1:54-67.

10. Loberg RD, Ying C, Craig M, Day LL, Sargent E, Neeley C, Wojno K, Snyder LA, Yan L and Pienta KJ. Targeting CCL2 with systemic delivery of neutralizing antibodies induces prostate cancer tumor regression in vivo. Cancer research. 2007; 67:9417-9424.

11. Germano G, Frapolli R, Belgiovine C, Anselmo A, Pesce S, Liguori M, Erba E, Uboldi S, Zucchetti M, Pasqualini F, Nebuloni M, van Rooijen N, Mortarini R, Beltrame L, Marchini S, Fuso Nerini I, et al. Role of macrophage targeting in the antitumor activity of trabectedin. Cancer cell. 2013; 23:249-262.

12. Panni RZ, Linehan DC and DeNardo DG. Targeting tumorinfiltrating macrophages to combat cancer. Immunotherapy. 2013; 5:1075-1087.

13. Cecchini MG, Dominguez MG, Mocci S, Wetterwald A, Felix R, Fleisch H, Chisholm O, Hofstetter W, Pollard JW and Stanley ER. Role of colony stimulating factor-1 in the establishment and regulation of tissue macrophages during postnatal development of the mouse. Development. 1994; 120:1357-1372.

14. Stanley ER, Guilbert LJ, Tushinski RJ and Bartelmez SH. CSF-1--a mononuclear phagocyte lineage-specific hemopoietic growth factor. J Cell Biochem. 1983; 21:151159.

15. Akashi K, Traver D, Miyamoto $\mathrm{T}$ and Weissman IL. A clonogenic common myeloid progenitor that gives rise to all myeloid lineages. Nature. 2000; 404:193-197.

16. Varol C, Landsman L, Fogg DK, Greenshtein L, Gildor B, Margalit R, Kalchenko V, Geissmann F and Jung S. Monocytes give rise to mucosal, but not splenic, conventional dendritic cells. The Journal of experimental medicine. 2007; 204:171-180.

17. Hettinger J, Richards DM, Hansson J, Barra MM, Joschko AC, Krijgsveld $\mathrm{J}$ and Feuerer M. Origin of monocytes and macrophages in a committed progenitor. Nature immunology. 2013; 14:821-830.

18. Yona S, Kim KW, Wolf Y, Mildner A, Varol D, Breker
M, Strauss-Ayali D, Viukov S, Guilliams M, Misharin A, Hume DA, Perlman H, Malissen B, Zelzer E and Jung S. Fate mapping reveals origins and dynamics of monocytes and tissue macrophages under homeostasis. Immunity. 2013; 38:79-91.

19. Geissmann F, Jung S and Littman DR. Blood monocytes consist of two principal subsets with distinct migratory properties. Immunity. 2003; 19:71-82.

20. Carlin LM, Stamatiades EG, Auffray C, Hanna RN, Glover L, Vizcay-Barrena G, Hedrick CC, Cook HT, Diebold S and Geissmann F. Nr4a1-dependent Ly6C(low) monocytes monitor endothelial cells and orchestrate their disposal. Cell. 2013; 153:362-375.

21. Auffray C, Fogg D, Garfa M, Elain G, Join-Lambert O, Kayal S, Sarnacki S, Cumano A, Lauvau G and Geissmann F. Monitoring of blood vessels and tissues by a population of monocytes with patrolling behavior. Science. 2007; 317:666-670.

22. Young MR, Ihm J, Lozano Y, Wright MA and Prechel MM. Treating tumor-bearing mice with vitamin D3 diminishes tumor-induced myelopoiesis and associated immunosuppression, and reduces tumor metastasis and recurrence. Cancer immunology, immunotherapy. 1995; 41:37-45.

23. Gabrilovich DI, Ostrand-Rosenberg S and Bronte V. Coordinated regulation of myeloid cells by tumours. Nat Rev Immunol. 2012; 12:253-268.

24. Delano MJ, Scumpia PO, Weinstein JS, Coco D, Nagaraj S, Kelly-Scumpia KM, O’Malley KA, Wynn JL, Antonenko S, Al-Quran SZ, Swan R, Chung CS, Atkinson MA, Ramphal R, Gabrilovich DI, Reeves WH, et al. MyD88-dependent expansion of an immature GR-1(+)CD11b(+) population induces $\mathrm{T}$ cell suppression and $\mathrm{Th} 2$ polarization in sepsis. The Journal of experimental medicine. 2007; 204:14631474.

25. Huang B, Pan PY, Li Q, Sato AI, Levy DE, Bromberg J, Divino CM and Chen SH. Gr-1+CD115+ immature myeloid suppressor cells mediate the development of tumor-induced $\mathrm{T}$ regulatory cells and T-cell anergy in tumor-bearing host. Cancer research. 2006; 66:1123-1131.

26. Hoechst B, Voigtlaender T, Ormandy L, Gamrekelashvili J, Zhao F, Wedemeyer H, Lehner F, Manns MP, Greten TF and Korangy F. Myeloid derived suppressor cells inhibit natural killer cells in patients with hepatocellular carcinoma via the NKp30 receptor. Hepatology. 2009; 50:799-807.

27. Ostrand-Rosenberg S and Sinha P. Myeloid-derived suppressor cells: linking inflammation and cancer. Journal of immunology. 2009; 182:4499-4506.

28. Sinha P, Clements VK, Bunt SK, Albelda SM and Ostrand-Rosenberg S. Cross-talk between myeloid-derived suppressor cells and macrophages subverts tumor immunity toward a type 2 response. Journal of immunology. 2007; 179:977-983.

29. Sieja K, Stanosz S, von Mach-Szczypinski J, Olewniczak 
$\mathrm{S}$ and Stanosz M. Concentration of histamine in serum and tissues of the primary ductal breast cancers in women. Breast. 2005; 14:236-241.

30. Medina V, Cricco G, Nunez M, Martin G, Mohamad N, Correa-Fiz F, Sanchez-Jimenez F, Bergoc R and Rivera ES. Histamine-mediated signaling processes in human malignant mammary cells. Cancer biology \& therapy. 2006; 5:1462-1471.

31. Triggiani M, Petraroli A, Loffredo S, Frattini A, Granata F, Morabito P, Staiano RI, Secondo A, Annunziato L and Marone G. Differentiation of monocytes into macrophages induces the upregulation of histamine $\mathrm{H} 1$ receptor. J Allergy Clin Immunol. 2007; 119:472-481.

32. Simon T, Gogolak P, Kis-Toth K, Jelinek I, Laszlo V and Rajnavolgyi E. Histamine modulates multiple functional activities of monocyte-derived dendritic cell subsets via histamine receptor 2. Int Immunol. 2012; 24:107-116.

33. Wang KY, Arima N, Higuchi S, Shimajiri S, Tanimoto A, Murata Y, Hamada T and Sasaguri Y. Switch of histamine receptor expression from $\mathrm{H} 2$ to $\mathrm{H} 1$ during differentiation of monocytes into macrophages. FEBS Lett. 2000; 473:345348.

34. Glatzer F, Mommert S, Kother B, Gschwandtner M, Stark $\mathrm{H}$, Werfel $\mathrm{T}$ and Gutzmer R. Histamine downregulates the Th1-associated chemokine IP-10 in monocytes and myeloid dendritic cells. International archives of allergy and immunology. 2014; 163:11-19.

35. Oda T, Morikawa N, Saito Y, Masuho Y and Matsumoto S. Molecular cloning and characterization of a novel type of histamine receptor preferentially expressed in leukocytes. The Journal of biological chemistry. 2000; 275:3678136786.

36. Dijkstra D, Leurs R, Chazot P, Shenton FC, Stark H, Werfel $\mathrm{T}$ and Gutzmer R. Histamine downregulates monocyte CCL2 production through the histamine $\mathrm{H} 4$ receptor. J Allergy Clin Immunol. 2007; 120:300-307.

37. Damaj BB, Becerra CB, Esber HJ, Wen Y and Maghazachi AA. Functional expression of $\mathrm{H} 4$ histamine receptor in human natural killer cells, monocytes, and dendritic cells. Journal of immunology. 2007; 179:7907-7915.

38. Yang XD, Ai W, Asfaha S, Bhagat G, Friedman RA, Jin G, Park H, Shykind B, Diacovo TG, Falus A and Wang TC. Histamine deficiency promotes inflammation-associated carcinogenesis through reduced myeloid maturation and accumulation of CD11b+Ly6G+ immature myeloid cells. Nature medicine. 2011; 17:87-95.

39. Martin RK, Saleem SJ, Folgosa L, Zellner HB, Damle SR, Nguyen GK, Ryan JJ, Bear HD, Irani AM and Conrad DH. Mast cell histamine promotes the immunoregulatory activity of myeloid-derived suppressor cells. Journal of leukocyte biology. 2014; 96:151-159.

40. Zheng Y, Xu M, Li X, Jia J, Fan K and Lai G. Cimetidine suppresses lung tumor growth in mice through proapoptosis of myeloid-derived suppressor cells. Molecular immunology. 2013; 54:74-83.

41. Kimura S, Wang KY, Tanimoto A, Murata Y, Nakashima $Y$ and Sasaguri $Y$. Acute inflammatory reactions caused by histamine via monocytes/macrophages chronically participate in the initiation and progression of atherosclerosis. Pathology international. 2004; 54:465-474.

42. Morichika $\mathrm{T}$, Takahashi HK, Iwagaki $\mathrm{H}$, Yoshino $\mathrm{T}$, Tamura R, Yokoyama M, Mori S, Akagi T, Nishibori M and Tanaka N. Histamine inhibits lipopolysaccharide-induced tumor necrosis factor-alpha production in an intercellular adhesion molecule-1- and B7.1-dependent manner. The Journal of pharmacology and experimental therapeutics. 2003; 304:624-633.

43. Gschwandtner M, Bunk H, Kother B, Thurmond RL, Kietzmann M, Werfel T, Baumer $\mathrm{W}$ and Gutzmer R. Histamine down-regulates IL-27 production in antigenpresenting cells. Journal of leukocyte biology. 2012; 92:2129.

44. Vannier E and Dinarello CA. Histamine enhances interleukin (IL)-1-induced IL-1 gene expression and protein synthesis via $\mathrm{H} 2$ receptors in peripheral blood mononuclear cells. Comparison with IL-1 receptor antagonist. The Journal of clinical investigation. 1993; 92:281-287.

45. Hansson M, Hermodsson S, Brune M, Mellqvist UH, Naredi P, Betten A, Gehlsen KR and Hellstrand K. Histamine protects $\mathrm{T}$ cells and natural killer cells against oxidative stress. Journal of interferon \& cytokine research. 1999; 19:1135-1144.

46. Hellstrand K, Asea A, Dahlgren C and Hermodsson S. Histaminergic regulation of NK cells. Role of monocytederived reactive oxygen metabolites. Journal of immunology. 1994; 153:4940-4947.

47. Martner A, Wiktorin HG, Lenox B, Ewald Sander F, Aydin E, Aurelius J, Thoren FB, Stahlberg A, Hermodsson S and Hellstrand $\mathrm{K}$. Histamine promotes the development of monocyte-derived dendritic cells and reduces tumor growth by targeting the myeloid NADPH oxidase. Journal of immunology. 2015; 194:5014-5021.

48. Vila-Leahey A, Oldford S, Marignani P and Marshall J. Histamine receptor 2 blockade reduces breast tumor development and metastasis (TUM9P.1010). The Journal of Immunology. 2015; 194:210.212.

49. Haile LA, Gamrekelashvili J, Manns MP, Korangy F and Greten TF. CD49d is a new marker for distinct myeloidderived suppressor cell subpopulations in mice. Journal of immunology. 2010; 185:203-210.

50. World Health Organization, Geneva. Cancer pain relief with a guide to opioid availability. 1996.

51. van Furth R and Diesselhoff-den Dulk MM. Dual origin of mouse spleen macrophages. The Journal of experimental medicine. 1984; 160:1273-1283.

52. List AF, Beaird DH and Kummet $\mathrm{T}$. Ranitidineinduced granulocytopenia: recurrence with cimetidine administration. Annals of internal medicine. 1988; 108:566- 
567.

53. Byron JW. Mechanism for histamine H2-receptor induced cell-cycle changes in the bone marrow stem cell. Agents and actions. 1977; 7:209-213.

54. Petit I, Szyper-Kravitz M, Nagler A, Lahav M, Peled A, Habler L, Ponomaryov T, Taichman RS, ArenzanaSeisdedos F, Fujii N, Sandbank J, Zipori D and Lapidot T. G-CSF induces stem cell mobilization by decreasing bone marrow SDF-1 and up-regulating CXCR4. Nature immunology. 2002; 3:687-694.

55. Ioannou M, Alissafi T, Lazaridis I, Deraos G, Matsoukas J, Gravanis A, Mastorodemos V, Plaitakis A, Sharpe A, Boumpas D and Verginis P. Crucial role of granulocytic myeloid-derived suppressor cells in the regulation of central nervous system autoimmune disease. Journal of immunology. 2012; 188:1136-1146.

56. Shi M, Shi G, Tang J, Kong D, Bao Y, Xiao B, Zuo C, Wang T, Wang Q, Shen Y, Wang H, Funk CD, Zhou J and Yu Y. Myeloid-derived suppressor cell function is diminished in aspirin-triggered allergic airway hyperresponsiveness in mice. J Allergy Clin Immunol. 2014; 134:1163-1174 e1116.

57. Osawa S, Kajimura M, Yamamoto S, Ikuma M, Mochizuki C, Iwasaki H, Hishida A and Terakawa S. Alteration of intracellular histamine $\mathrm{H} 2$ receptor cycling precedes antagonist-induced upregulation. Am J Physiol Gastrointest Liver Physiol. 2005; 289:G880-889.

58. Alewijnse AE, Smit MJ, Hoffmann M, Verzijl D, Timmerman $\mathrm{H}$ and Leurs R. Constitutive activity and structural instability of the wild-type human $\mathrm{H} 2$ receptor. Journal of neurochemistry. 1998; 71:799-807. 